\title{
The Impact of the Financial Flexibility on the Performance: An Empirical Study on a Sample of Jordanian Services Sector Firms in Period (2010-2017)
}

\author{
Zaher Abdel Fattah Al-Slehat ${ }^{1}$ \\ ${ }^{1}$ Assistant Professors, Faculty of Business, Tafila Technical University, Jordan \\ Correspondence: Zaher Abdel Fattah Al-Slehat, Tafila Technical University, At-Tafila, P.O. Box 179, Tafila, \\ 66110, Jordan. E-mail: Zalabadi@Yahoo.com
}

\author{
Received: March 13, 2019 \\ Accepted: April 22, 2019 \\ Online Published: May 9, 2019 \\ doi:10.5539/ijbm.v14n6p1 \\ URL: https://doi.org/10.5539/ijbm.v14n6p1
}

\begin{abstract}
This study aims at investigating the impact of the financial flexibility on the performance on a sample of Jordanian services sector firms for the period 2010-2017.

The researcher used the analytical descriptive method on a sample consisted of 18 Jordanian firms listed in Amman Stock Exchange. The Multiple Linear Regression Analysis was used to examine the hypotheses of the study. The study revealed that there was an effect of the financial flexibility on the performance of the Jordanian services sector firms. The study recommended paying an increasing attention to the indicators of the financial flexibility by linking it with the performance to achieve a competitive advantage that could be reflected in the existence, development and continuity of the firms.
\end{abstract}

Keywords: financial flexibility, performance, cash flow, cash holding, Liquidity, interest coverage ratio, operating margin ratio.

\section{Introduction}

Due to great development in service sector activity and the diversity of its investment tools, it becomes necessary for the administrative leaderships to care about its financial management by adapting an effective system that all financial decisions are made through to positively appear, as a result, in the financial, operating and administrative performance. To achieve this, the financial administrations should concentrate on its financial indicators which will be reflected in its future goals; one of these indicators is the financial flexibility which has a vital role in achieving the existence, development and continuity of the firms

While Jordanian services sector works in a dynamically developing environment in the field of services which are provided to the beneficiaries and to enable this sector to persist in competition appropriately, it seems important to pay attention to some unusual qualities, especially the financial flexibility, in order to respond accurately and quickly to any competitive threats and changes in the investment environment.

In this regard, Setianto and Kusumaputra (2017) indicated that the financial flexibility is a firm's ability to mobilize its financial resources in facing future uncertainties. Hence, financially flexible firms will enjoy easier access to low-cost external financing in order to meet their financing needs, which may arise from an unexpected decrease in income as well as sudden new investment opportunities.

\section{Theoretical Framework}

\subsection{The Financial Flexibility}

Financial flexibility was referred to in Modigliani and Miller (1963) as reserves of untapped borrowing power. The financial flexibility is defined as the ability of the organization in response to changes in the work conditions; changes are like environment, technology, markets and structure (Smith, 2005). Whilst Nouri and Jafari (2016) and Lee and Lee (2006) defined it as company's capability to obtain financial resources in order to have a timely reaction to any future unexpected events in cash flow and to maximize the company's value.

Ang and Smedema (2011) and Gamba and Triantis (2008) defined financial flexibility as the firms' capability to manage the negative shocks in income, avoiding any financial crisis and getting benefits for the positive shocks 
for the easily available investment opportunities. More to add, Denis and Mckeon (2010) stated that unused debt capacity was an important source of financial flexibility as it is the most important determinant of capital structure.

\subsubsection{Financial Flexibility (Types, Levels and Sources)}

The administrative leadership attempted to make the cash flows flexible throughout the organization; this means the financial flexibility is one of the most important aspects for the firms' managers, especially in determining their capital structure and the amount of debt (Brounen, et al, 2005; Arslan, et al, 2010).

According to Hisrich (2004), the financial flexibility is divided into: 1- the operational flexibility 2- the structure flexibility 3 - the strategic flexibility 4 - the financial flexibility.

This means that the financial flexibility is one of the most distinguishing features in the firms especially in the operational and easy structure; the firm has a big flexibility in financing the new property without delay or reduction in profits in a way that ensure the safety of the financial structure in firm (John et al, 2007). However, the financial flexibility is considered as a source of anxiety for the directors of business and the financial institutions as it represents the capacity to avoid lack of investment and financial crises (Denis, 2011; Graham and Harvey, 2001).

Many researchers agreed upon the idea of being financially flexible to get financing in any economic conditions; the financially flexible firms are able to avoid financial crises or negative shocks.

\subsubsection{Financial Flexibility Levels}

The firms might use many alternates (levels) to be financially flexible. Figure 1 below illustrates these levels. (Bancel, 2012)

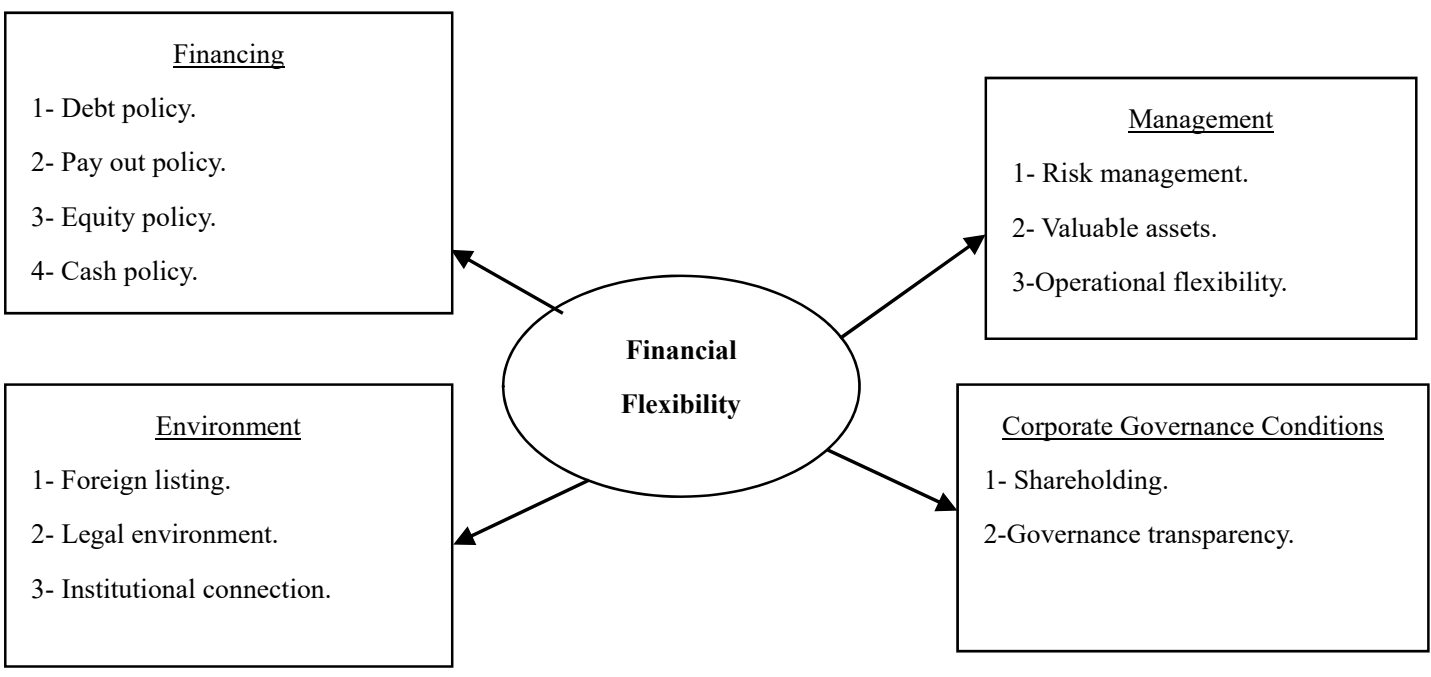

Figure 1. The available levels of financial flexibility for firms

Source: Adapted from Bancel, 2012

Figure 1 illustrates that all these levels lead firm to a higher or lower level of the financial flexibility; to reach a high level of financial flexibility, firms should follow financing policy that includes debt policy, pay out policy, equity policy, and cash policy. The second level is dedicated to risk management and operational flexibility, while the third level is for the institutional environment and the last level is for corporate governance conditions in the firms.

\subsubsection{Sources of the Financial Flexibility}

Sayyad and Ulvenas (2012) referred to a list of sources for the financial flexibility such as:

1- Cash holdings and liquidity management.

2- Capital structure and debt

3- Flexible equity payouts, and 


\section{4- Other financial policies}

\subsubsection{Cash Flows}

To achieve the aim of this study, the indicator of cash flows was adapted as a measure of financial flexibility in the firms of the Jordanian services sector. Gitman (2002) indicated that the cash flows were considered as lifeline for firms and the main cornerstone for the financial director in administrating the daily financial issues, planning and making strategic decisions aiming at creating shareholders' value.

Mainly, the firms focus on the operational cash flow that is used in the administrative decision and the free cash flow that is observed by the investors in the capital market. These cash flows are divided into:

1- The operational cash flows: which are the internal and external cash flows concerning the process of purchases and services of firms.

2- The investment cash flows: which are related to the purchase or sale of the fixed assets.

3- The financial cash flows: which are related to the financing transactions by debt or equity.

\subsubsection{Cash Holding}

A firm's cash holdings consist of its money in hand, deposits in banks, and short-term investments whose purpose is to receive a higher return than to do deposits but that can be converted into cash quickly if necessary. (Ma and Jin, 2016)

Cash holdings may be particularly useful for firms facing real investment friction because cash holdings are a realized value at the time of making decision of investment for the coming year. By making investments with cash holdings, firms can avoid potential adjustment costs associated with investing based on uncertain cash flows (Chen, 2016).

\subsubsection{Liquidity}

Brealey et al (2015) Quiry et al (2005) indicated that the liquidity is a firm's ability to sell an asset on short notice at close to the market price. That is, it refers to the ability to convert an instrument into cash quickly and without loss of value. There are several measures of liquidity:

A. Current Ratio: The current ratio is the ratio of current assets to current liabilities.

B. Cash Ratio: The company's most liquid assets are its holdings of cash and marketable securities. Cash ratio $=($ Cash and cash equivalents $) /$ current liabilities.

C. Quick (Acid-Test) Ratio: managers often exclude inventories and other less liquid components of current assets when comparing current assets to current liabilities. They focus instead on cash, marketable securities. This result in the quick ratio: Quick ratio $=$ (Current assets excluding inventories)/ current liabilities.

\subsection{The Performance}

The administrative leaderships make every effort in the financial flexibility to ensure the best performance that appears in the share values, the equity of shareholders and, as a result, achieving the goals of firms. The firms utilize a set of financial and non-financial indicators to assess the performance including the profitability ratio and efficiency in administrating the assets and transactions as illustrated in Figure 2 below (Ross, et al, 2010; Smith, 2005), knowing that the performance in services sector needs a high level of accuracy to ensure a higher levels of efficiency and the quality of services (Shah, 2007; Tarullo, 2008).

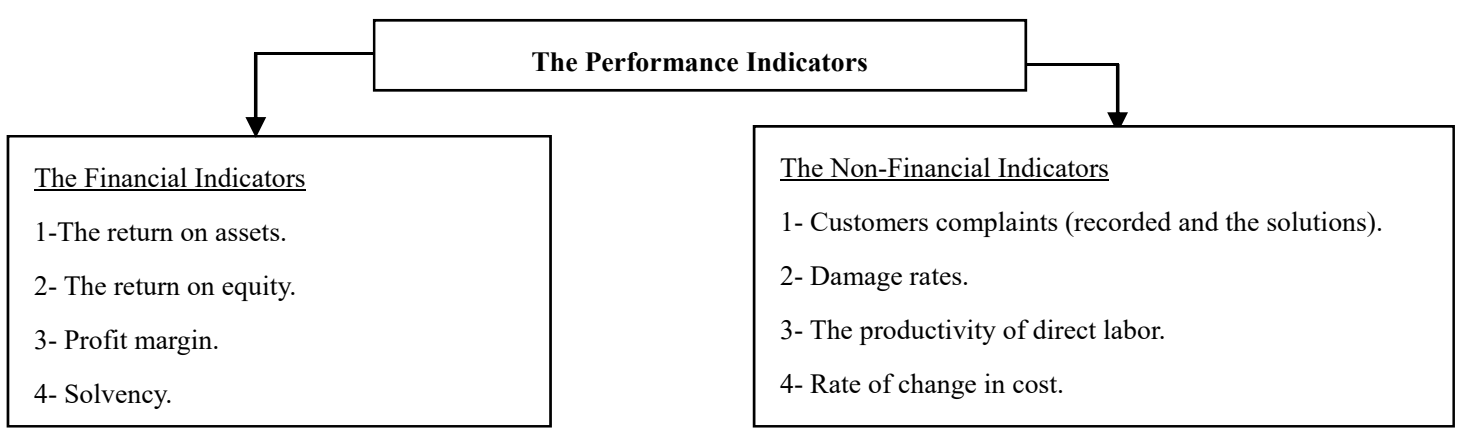

Figure 2. The performance indicators 
The performance indicators also include other measurements such as interest coverage ratio and operating margin ratio (Gitman, 2002).

1- Interest coverage ratio: It refers to the firms' capacity to pay the amounts of the contractual interest; the increase in its value means the firm is able to fulfill its obligations.

2- Operating margin ratio: This ratio, according to Tulsian (2014), aims to measure the operating efficiency of the administration and count each gained dinar from the operating incomes. Moreover, it refers to the basic business processes by omitting the effect of the non-operating profits and losses that are not related to the basic processes. This is also used for the administrative purposes and the credit analysis, so it is considered as a multiple-purposes measure; the increase in this rate does not only refer to an increase in the firm's sales, but also refers to a reduction in its operating expenses.

\section{Literature Review}

Ma and Jin (2016) investigated the impact of investment scale on driving the relationship between the financial flexibility and the performance of the firms listed in the Chinese Bursa in the period 2010-2013. The study was conducted on a sample of 1496 observations. The findings of the study revealed that there was a big effect on the financial flexibility on both: the investment and the performance. Thus, the Chinese firms tended to emphasize the investment expansion to improve the firm performance.

Chen and Hsiao (2014) examined the sensitivity of cash flow and the financial flexibility through concentrating on any effect of the internal owners on the financial flexibility for the firms. By conducting this study on American firms during the period 1992-2009, the study revealed that the relationship between the corporate governance, the cost of the external financing and the internal ownership affected the financial flexibility through agency costs. Moreover, the study stated that the financial flexibility became higher when the ownership of the executive directors was less than $8 \%$, and also when the ownership of non-executive directors was, in average, between $(0.12 \%-0.43 \%)$; the effect of the ownership of the non-executive directors on the financial flexibility was low.

On the other hand, Harris (2014) studied the relationship between the financial flexibility (through stock buyback) and the capital structure for all listed in the database of the financial, statistical and market information during the period 1970-2013, except those firms with codes 6000-6999 and 4900-4999, as the buyback process was not listed in 1970 or the sales of these firms or their total assets were less than zero. The results of the study found out that the financial flexibility was one of the higher considerations by the financial managers in determining the level of the fixed debt and the stock buyback improved the financial flexibility.

Ayaydin et al. (2013) explored the effect of the financial flexibility on the investment and the performance of firms in East Asia in period 1994-2009 on a sample of 1068 firms. The study focused on the Asian Crisis between 1997-1998 and Credit Crisis between 2007-2009. The study showed that the financial flexibility was a main factor for investment and performance especially during the Asian Crisis; the firms that had a greater level of financial flexibility before the crisis enjoyed a greater capacity for the investment opportunities and relied on the internal money. The study also revealed that the firms that were financially flexible prior to this crisis had a greater ability to take investment opportunities, relied on the availability of internal funds to invest, and performed better than the less flexible firms during the crisis.

Sayyad and Ulvenas (2012) studied the significance of the varied sources of the financial flexibility that enabled firms to confront the negative shocks or the unexpected investment opportunities during the years 1995-2011. The study concluded that there were notable differences among the sectors in the way of solving the lack of cash; these sectors sell their assets to face the cash deficit.

However, Marchica and Mura (2010) stated the impact of financial flexibility was both statistically significant and economically sizeable. It also revealed that the financially flexible firms not only invested more, but also invested better. The study was conducted on all firms listed in the Britain market during 1965-2008 except the financial firms because of the difference in their capital structure, so the population of the study was 677 firms. To analyze the performance, the researchers collected the data of the monthly returns of the companies' shares among other financial indicators.

On other hand, Arslan et al. (2010) studied the impact of the financial flexibility on investment and performance on a sample of 1068 firms affected by the Asian crisis during 1997-1998. These firms were listed in the markets of Hon Kong, Indonesia, Malaysia, South Korea and Thailand as they were the most affected Asian economies by this crisis. The study found out the firms that were financially flexible prior to the crisis had a greater ability to take investment opportunities, relied much less on the availability of internal funds to invest and performed 
better than less flexible firms during the crisis. The results also suggested that leverage-based flexibility indicators were better predictors of corporate investment and performance.

\subsection{This Study}

This study differs from previous studies as it discusses the financial flexibility and the performance. Both of them are practically and scientifically significant in finance. Practically, these indicators reflect the capacity of the services sector in utilizing money for financing its assets, investments and, consequently, the realized cash flows. On the other hand, these indicators show the ability of this sector in financing the incomes and the effectiveness of the investment, operating and financing policy of the administration.

Scientifically, the subject of the indicators of the financial flexibility is still a field of research and interest by researchers, the administrations of the services sector and other sectors in general.

\section{Statement of the Problem}

The statement of the problem was represented in a deficiency of relying on the financial ratios to measure the performance as this caused an ignorance of the time value of money on one hand, and a lack the conceptual awareness of the financial flexibility, on the other hand. Consequently, this study attempted to explore the impact of the financial flexibility on the performance during the period 2010-2017. The statement of the problem is stated in the following questions:

A. Is there an impact of the financial flexibility on the performance measured by Interest coverage ratio?

B. Is there an impact of the financial flexibility on the performance measured by Operating margin ratio?

\section{Significance of the Study}

The significance of the study is demonstrated in the significance of the financial flexibility for the administrative leaderships in the Jordanian services sector and the adopted ways to reflect its effect on performance. The points below highlight this significance:

1- The importance of the financial flexibility and its impact on the financial decisions that are reflected in liquidity, profitability and safety.

2- This study links between variables measured by the tools of the financial flexibility; the financial flexibility is measured by the cash flow, cash holding and liquidity. Whilst the performance is measured by interest coverage ratio and operating margin ratio. These variables are working to direct the financial decisions in a way that positively appear in the shareholders' value and, as a result, in the market share. Moreover, it is important for market participants such as investors, shareholders, brokers, creditors and others in order to enhance the activity of the ASE.

3- Exploring the expected impact of the financial flexibility, if there is any, on the performance.

\section{Hypotheses of the Study}

H1: There is no statistically significant impact at $(\alpha \geq 0.05$ ) of the financial flexibility on the performance that is measured by interest coverage ratio.

$\mathrm{H} 2$ : There is no statistically significant impact at $(\alpha \geq 0.05)$ of the financial flexibility on the performance that is measured by operating margin ratio.

\section{Research Methodology}

The study adapted the analytical descriptive method by using the indicator of the financial flexibility and the performance indicators.

\subsection{Population and Sample of Study}

The populations of study are all working services firms listed in Amman Stock Exchange in the period between 2010-2017. Additionally, 18 firms were chosen to be the sample of study under the following conditions:

1- Availability of all required data to examine the variables.

2- No merger process occurred.

3- The fiscal year ends in $31^{\text {st }}$ of December.

4- Availability of the financial reports for all firms.

\subsection{Data Collection}

In the current study, the annual financial reports of firms under study, the reports issued by Amman Stock 
Exchange, a plethora of books, research papers, articles, theses that relate to the topic of this study were adopted as sources of data to cover the theoretical part.

\subsection{Model of Study}

The following model is adapted to present the specific views of the problem and its features concerning the impact of the financial flexibility on the performance. Ayaydin et al. (2013), Ma and Jin (2016) and Sayyad and Ulvenas (2012) and Estwick (2015) Gatsi et al. (2013) were used to deal with the independent variable i.e. the cash flows, cash holding and liquidity as an indicator to measure the financial flexibility. On the other side, Arslan, et al, (2010) was also adapted to study the two other dependent variables: interest coverage ratio and operating margin ratio.

Figure 3 below illustrates this impact:

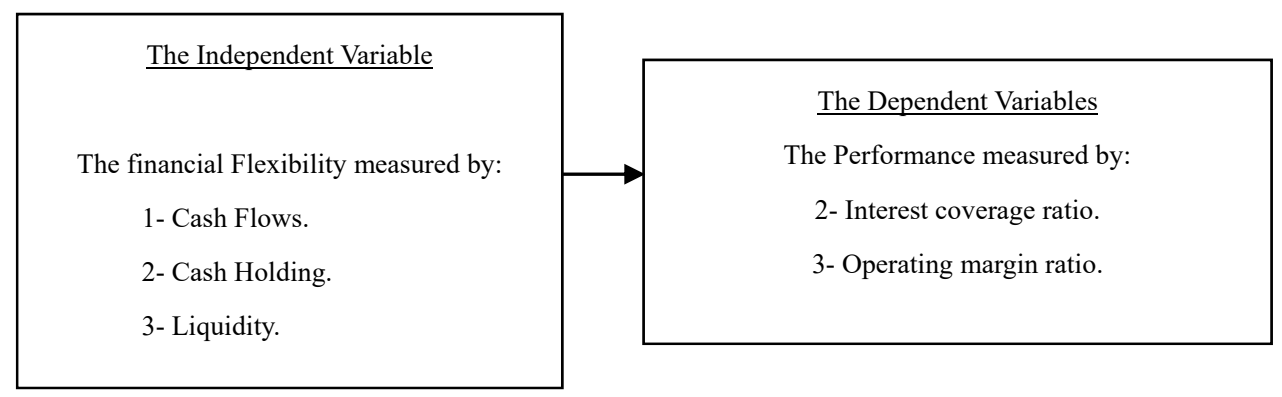

Figure 3. The model of study

The method involves tow regressions:

$1=\mathrm{ICR}=\alpha+\mathrm{B} 1 \mathrm{CF}+\mathrm{B} 2 \mathrm{CH}+\mathrm{B} 3 \mathrm{~L}+\mathrm{e}$

$2=\mathrm{OMR}=\alpha+\mathrm{B} 1 \mathrm{CF}+\mathrm{B} 2 \mathrm{CH}+\mathrm{B} 3 \mathrm{~L}+\mathrm{e}$

7.4 Variables of Study

The variables of study were measured according to the following:

\subsubsection{The Independent Variable}

The independent variables were the indicators of the financial flexibility measured by cash flow, cash holding and liquidity. They were measured as follows (Ross, et al, 2003; Sayyad and Ulvenas, 2012; Ma and Jin, 2016; Setianto and Kusumpautra, 2017; Droj 2018; Gatsi et al 2013; www.ase.com.jo).

\section{A. Cash Flows:}

Cash flow= Cash Balance (Beginning) + Net cash flow from (used in) operating Activities + Net cash flow from (used in) investing Activities + Net cash flow from (used in) Financing Activities+ Differences in Exchange.

B. Cash Holding:

Cash Holding $=($ Cash + Short term investment $) /$ Total assets

C. Liquidity

Quick ratio $=($ Current assets excluding inventories $) /$ current liabilities

\subsubsection{The Dependent Variables}

The dependent variables were the indicators of the performance measured by the return on assets, the interest coverage ratio and the operating margin ratio. They were measured as follows (Arslan, et al, 2010):

\section{A- Interest Coverage Ratio}

Interest Coverage Ratio $=$ Earnings before Interest and Tax /Interest Expense

B. Operating Margin Ratio

Operating Margin Ratio = Operating Income / Sales 


\section{The Statistical Analysis}

\subsection{The Descriptive Analysis}

Table 1 below shows the descriptive analysis for the variables of the study. The table illustrates the mean and the standard deviations for the independent variable, the financial flexibility, measured by the cash flows (CF), cash holding $(\mathrm{CH})$ and Liquidity $(\mathrm{L})$, and the dependent variable, the performance, measured by the interest coverage ratio (ICR) and the operating margin ratio (OM).

Table 1. Descriptive analysis for the variables of the study

\begin{tabular}{llllll}
\hline & CF & CH & L & ICR & OM \\
\hline Mean & 11943045 & 253934526 & 5.84067 & 135.55 & 0.1703 \\
Std. Dev. & 48688416 & 77939320 & 4.95522 & 491.7 & 0.1742 \\
Probability & 0.000 & 0.000 & 0.00 & 0.000 & 0.000 \\
Observations & 139 & 139 & 139 & 139 & 139 \\
\hline
\end{tabular}

Based on the results shown in Table 1, the sample during the period of the study was fluctuating in term of the CF, CH and L, the mean was 11943045 JD , 253934526 JD and 5.84067 with standard deviation of 48688416 JD , $77939320 \mathrm{JD}$ and 4.95522 ; this is due to the difference in size and age of firm. Additionally, the mean of ICR and OM were 135.55 and 0.1703 respectively with standard of deviations of 491.7 and 0.1742 .

Table 1 reveals that there is a convergence of results in the performance indicators despite of the difference in age and size of the population; this refers to the efficiency in the investment and the operational process in a way that appears in the maximizing profit which leads to an increase in the value of the firms.

\subsection{Unit Root Test}

Table 2 below illustrates the results of Unit Root Test and Levin-Lin-Chu Test. The P-value for all variables was less than the statistical significance level (0.05), so all dependent and independent variables are described as stable during the period of study

Table 2. Unit root test

\begin{tabular}{llll}
\hline Abbreviation & variables & P-value & t-statistic \\
\hline $\mathrm{CF}$ & Cash Flow & 0.00 & $4.03858-$ \\
$\mathrm{CH}$ & Cash Holding & 0.00 & -6.38515 \\
$\mathrm{~L}$ & Liquidity & 0.00 & -7.40626 \\
$\mathrm{ICR}$ & Interest Coverage Ratio & 0.00 & $8.94855-$ \\
OMR & Operating Margin Ratio & 0.00 & -13.5152 \\
\hline
\end{tabular}

\subsection{Results of Testing Hypotheses and Discussion}

The First hypothesis: There is no statistically significant impact at $(\alpha \geq 0.05)$ of the financial flexibility on the performance that is measured by the interest coverage ratio.

The results of examining impact of the financial flexibility on the performance measured by the ICR are illustrated in Table 3 below. 
Table 3. Results of testing the first hypothesis about ICR

\begin{tabular}{lllll}
\hline $\begin{array}{l}\text { Dependent Variable: ICR } \\
\text { Method: Panel Least Squares } \\
\text { Cross-sections included: } 18\end{array}$ & & & \\
Model 1 = ICR = $\alpha+$ B1CF + B2CH + B3L + e & & & & \\
\hline Variable & Coefficient & Std. Error & t-Statistic & Prob. \\
\hline $\mathrm{CF}$ & 1.869193 & 7.240250 & 2.581670 & 0.0111 \\
$\mathrm{CH}$ & 0.590704 & 0.099806 & 5.918526 & 0.0000 \\
$\mathrm{~L}$ & 27.20528 & 7.561064 & 3.598075 & 0.0005 \\
R-squared & 0.383664 & Mean dependent var & 135.8952 \\
Adjusted R-squared & 0.367861 & S.D. dependent var & 503.3296 \\
S.E. of regression & 400.1832 & Akaike info criterion & 14.85422 \\
Sum squared resid & 18737148 & Schwarz criterion & 14.94664 \\
Log likelihood & -894.6804 & Hannan-Quinn criter. & 14.89176 \\
F-statistic & 24.27721 & Durbin-Watson stat & 1.387565 \\
Prob(F-statistic) & 0.000000 & & & \\
\hline
\end{tabular}

Table 3 presents the results of the multiple regressions related to the first hypothesis of the study. The results of the analysis indicated that the value of Probability reached $(0.000)$ which means that there an impact of the financial flexibility on the performance measured by the ICR since calculated F value (24.27721) was more than the tabulated value of F (2.60) at $(\alpha \geq 0.05)$. Moreover, the value of Durbian-Watson test (1.38) indicated that there is no autocorrelation between the errors in the regression equation within the acceptable limits for this test. So the results refer not to accept the null hypothesis and accept the alternative hypothesis which indicates that there is an impact of the financial flexibility on the performance measured by the ICR.

Additionally, the table showed that the value of the coefficient of determination $\left(\mathrm{R}^{2}\right)$ was $(0.38)$ which means that the financial flexibility explains 0.38 of change in Interest coverage ratio and 0.62 is by other factors.

This means the important role of the financial flexibility is to improve the performance in the services sector through creating profitable investment opportunities that enable this sector to enter the local and international markets. This preserves the loyalty of the stakeholders in this sector, increases the flexibility in the performance and improves both the ability to cover the interest due to borrowing and the solvency of the firms.

The second hypothesis: There is no statistically significant impact at $(\alpha \geq 0.05)$ of the financial flexibility on the performance that is measured by the operating margin ratio.

The result of examining the impact of the financial flexibility on the performance measured by the (OM) is illustrated in Table 4 below:

Table 4. Results of testing the second hypothesis about MO

\begin{tabular}{lllll}
\hline $\begin{array}{l}\text { Dependent Variable: OM } \\
\text { Method: Panel Least Squares }\end{array}$ & & & & \\
Cross-sections included: 18 & & & & \\
Model 2 = OMR = $\alpha+\mathrm{B} 1 \mathrm{CF}+\mathrm{B} 2 \mathrm{CH}+\mathrm{B} 3 \mathrm{~L}+\mathrm{e}$ & & & & \\
Variable & Coefficient & Std. Error & t-Statistic & Prob. \\
$\mathrm{CF}$ & 6.579241 & 1.677125 & 3.922927 & 0.0002 \\
$\mathrm{CH}$ & -9.305945 & 9.255929 & -0.100540 & 0.9201 \\
$\mathrm{~L}$ & 0.016524 & 0.001495 & 11.04931 & 0.0000 \\
R-squared & 0.966301 & Mean dependent var & 0.171646 \\
Adjusted R-squared & 0.957078 & S.D. dependent var & 0.176032 \\
S.E. of regression & 0.036469 & Akaike info criterion & -3.592206 \\
Sum squared resid & 0.126352 & Schwarz criterion & -2.971644 \\
Log likelihood & 246.1246 & Hannan-Quinn criter. & -3.340153 \\
F-statistic & 104.7730 & Durbin-Watson stat & 1.765430 \\
Prob(F-statistic) & 0.000000 & & & \\
\hline
\end{tabular}

According to Table 4, the result of Durbin-Watson test is (1.76). This means it is within the acceptable limits. 
And the results of the analysis indicated that the value of Probability reached $(0.000)$ which means that there was an impact of the financial flexibility on the performance measured by the OM since calculated F value (104.7730) was more than the tabulated value of F (2.60) at $(\alpha \geq 0.05)$. Whilst, the results refer to accept the alternative hypothesis which indicates there is an impact of the financial flexibility on the performance measured by the OM. Additionally, coefficient of determination of the independent variable on the dependent variable was $96 \%$; it demonstrates that the reason of change of performance measured by the $\mathrm{OM}$ is due to the independent variable and $4 \%$ is by other factors.

These results assured the significance of the financial flexibility in improving the operating efficiency of the administration and positively reinforced the performance in this sector to face either positive or negative bigger financial shocks; this will create profitable investment opportunities that return on the sector altogether.

The findings of the study agreed with the results of the previous studies (MA \& Jin, 2016; Ayaydin et al., 2013; \& Arslan et al., 2010) that highlighted the vital role of the financial flexibility on the performance that is measured by ICR and OM in the Jordanian services sector which might positively appear in creating prosperous investment opportunities.

\section{Conclusions and Recommendations}

The study comes out with the following conclusions:

1- The financial flexibility is considered as a main criterion of the financial decisions in the firms to direct the investments towards profitable investment opportunities.

2- There is a positive impact of the financial flexibility that is measured by the cash flows, cash holding and liquidity on the performance indicators altogether in the Jordanian services sector firms.

In light of the results of this study, it is recommended to:

1- Pay deep attention on the indicators of the financial flexibility and link them with the concept of performance to make a competitive advantage that enable these firms to exist, grow and continue.

2- Train increasingly the financial analysts and employees in the Jordanian services sector to be able to enter the international markets and to expand investment opportunities that lead to increase income and to cause a positive reflection on ICR and OM.

3- Take the indicators of the financial flexibility into consideration by the Central Bank of Jordan to measure the efficiency of the administrations in the firms.

\section{References}

Ang, J., \& Smedema, A. (2011). Financial Flexibility: Do firms Prepare for Recession? Journal of corporate Finance, 17(3), 774-787. https://doi.org/10.1016/j.jcorpfin.2011.02.001

Arslan, O., Florackis, C., \& Ozkan, A. (2010). Financial Flexibility Corporate investment and Performance. University of Liverpool, United Kingdom.

Ayaydin, A., Florackis, C., \& Ozkan, A. (2013). Financial Flexibility Corporate investment and Performance: Evidence from Financial Crises. Review of Quantitative Finance and Accounting, 42(2), 211-250. https://doi.org/10.1007/s11156-012-0340-x

Bancel, F. (2012). Focus on Financial Flexibility, Bankers, Markets and investors. Escp Euroop, 60-65.

Brealey, R., Myers, S., and Marcus, A. (2015). Fundamentals of corporate finance (8th ed.). McGraw hill education, New York.

Brounen, D., Jong, A. D., \& Koedijk, K. (2005). Capital Structure policies in Europe: Survey Evidence, ERIM. Journal of Economic literature (JEL).

Chen, L. (2016). Corporate Investments, Cash Flows and Cash Holdings: Evidence from the Oil Industry before and after the Financial Crisis. Accounting and Finance Research, 5(4). https://doi.org/10.5430/afr.v5n4p192

Chen, N., \& Hsiao, E. N. (2014), Insider Ownership and financial Flexibility. Applied Economics, 46(29), 3609-3629. https://doi.org/10.1080/00036846.2014.937035

Denis, D. J. (2011). Financial flexibility and corporate liquidity. Journal of Corporate Finance, 17(3), 667-674. https://doi.org/10.1016/j.jcorpfin.2011.03.006

Denis, D. J., \& Mckeon, S. B. (2010). Debt Financing and Financial Flexibility Evidence form pro-active Leverage Increases. American Finance Association. 
Droj, L. (2018). Considerations regarding the evolution of the liquidity and solvency indicators of the most important Romanian production companies in the period 2014-2017, The Annals of the University of Oradea. Economic Sciences, Tom XXVII(2), 94-101.

Estwick, L. (2015). The Impact of Principal-principal Conflict on Financial Flexibility in Transition Economies: A Study of Caribbean Firms. Journal of Eastern Caribbean Studies, 40(2), 99-123.

Gamba, A., \& Triantis, A. (2008). The Value of Financial Flexibility. Forthcoming Journal of Finance, 63(5), https://doi.org/10.1111/j.1540-6261.2008.01397.x

Gatsi, J. K., Gadzo, S. G., \& Akoto, R. K. (2013). Degree of Financial and operating Leverage and Profitability of Insurance Firms in Ghana. International Business and Management, 7(2), 57-65. https://doi.org/10.3968/j.ibm.1923842820130702.1060

Gitman, L. J. (2002). Principle of managerial Finance (10th ed.). Prentice Hall.

Graham, J. R., \& Harvey, C. R. (2001). The theory and practice of corporate finance: Evidence from the field. Journal of financial economics, 60(2-3), 187-243.

Harris, C. (2014), Financial Flexibility and capital Structure, Elon University. https://doi.org/10.1016/S0304-405X(01)00044-7

Hisrich, R. (2004). Small Business Solution: How to fix and Prevent the Thirteen Biggest Problems that Derail Business. New York: MCGraw-Hill.

John, B., Guerand, J., \& Schwartz, A. (2007). Quantitative Corporate Finance. Springer Science and Business Media, LLC, New York, USA.

Lee, C. F., \& Lee, A. C. (2006). Encyclopedia of finance. Springer Science and Business media INC, USA.

Ma, C. A., \& Jin, Y. (2016). What drives the relationship Between Financial Flexibility and Firm Performance: Investment Scale or investment efficiency? Evidence from China. Emerging Markets and Trade, 52, 2043-2055. Taylor and Francis group. https://doi.org/10.1080/1540496X.2015.1098036

Marchica, M. T., \& Mura, R. (2010). Financial Flexibility Investment Ability and firm value: Evidence from firm with spare debt capacity. Financial Management, 39(4), 1339-1365. https://doi.org/10.1111/j.1755-053X.2010.01115.x

Modigliani, F., \& Miller, M. (1963). Corporate Income Taxes and the Cost of Capital: A Correction. The American Economic Review, 53(3), 433-443.

Nouri, M., \& Jafari, S. M. (2016). The Impact of Financial Flexibility on Investment Efficiency ( Over-investment and Under-investment) with Respect to Managerial Ownership in the Firs Listed in Tehran Stock Exchange. ICP Business, Economics and Finance, 3(2), 18-22.

Quiry, P., Dallocchio, M., Fur, Y. L., \& Salvi, A. (2005). Corporate finance theory and practice.

Ross, S. A., Westerfile, R. W., \& Jaff. (2003). Corporate finance (6th ed.). McGraw-Hill Irwin.

Ross, S. A., Westerfile, R. W., \& Jordan, B. D. (2010). Fundamentals of corporate finance (9th ed.). McGraw-Hill Irwin.

Sayyad, K. P., \& Ulvenas, J. A. (2012). Examining the Sources of Financial Flexibility, Published master thesis in finance. Department of Business administration, Lund University.

Setianto, R., \& Kusumpautra, A. (2017). Corporate finance flexibility, investment activities, and cash holding: Evidence from Indonesia. Indonesian capital market Review, 9, 75-85. https://doi.org/10.21002/icmr.v9i2.7470

Shah, A. (2007). Budgeting and Budgetary institutions, the world Bank Library of Congress cataloging in Publication data, USA.

Smith, M. (2005). Performance Measurement and Management A strategic Approach to Management Accounting.

Tarullo, D. K. (2008). Banking on Basel 1: The Future of international Financial Regulation, Library of Congress Cataloging in Publication data, USA.

Tulsian, M. (2014). Profitability Analysis (A comparative Study of SALL and TATA). Journal of Economics and Finance, 3(2), 19-22. https://doi.org/10.9790/5933-03211922 


\section{Copyrights}

Copyright for this article is retained by the author(s), with first publication rights granted to the journal.

This is an open-access article distributed under the terms and conditions of the Creative Commons Attribution license (http://creativecommons.org/licenses/by/4.0/). 